\title{
Seleksi Varietas Partisipatif Terhadap Galur-Galur Elit Padi Gogo di Lahan Petani
}

\section{Participatory Varietal Selection Elites Upland Rice at Farmer's Field}

\author{
Aris Hairmansis, Supartopo, Suwarno \\ Balai Besar Penelitian Tanaman Padi, Subang, Jawa Barat \\ *email : a.hairmansis@gmail.com
}

ABSTRACT

The adoption of new rice varieties by farmers is one of success indicators in rice breeding programs. While breeders have an ability to select the best rice lines, farmer's preferences on rice varieties may be different to breder's and are vary among the regions. Participatory varietal selection (PVS) was developed to increase selection efficiency by involving farmers in the selection programs. Two PVS programs were conducted during wet season 2012-2013 in two central areas of upland rice, Cianjur (West Java) and Kebumen (Central Java). Ten elite upland rice breeding lines and 4 new rice varieties were evaluated at farmer's field in both sites. Each genotype was grown by one co-operator farmer in $2000 \mathrm{~m}^{2}$ to $2500 \mathrm{~m}^{2}$ plot. Crops were managed by the farmers based on recommended practices from researchers. Selection was conducted by 20 to 22 farmers in each location before harvest. Variations in farmer's preference to the upland rice breeding lines revealed in both locations. Result from the present study showed the agreement between preference score of varieties based on PVS and phenotypic acceptability score based on breeder's perspective. Interestingly, genotype with high preference score were not necessary having high yield indicated that yield component is not solely criteria for variety adoption by farmers. The importance of PVS approach to increase adoption rate, genetic diversity and seed diffusion in upland areas are discussed in this paper.

Keywords: Selection, Participatory, Upland Rice

\section{INTISARI}

Salah satu indikator keberhasilan program pemuliaan adalah diadopsinya varietas unggul oleh petani. Meskipun pemulia memiliki kemampuan untuk memilih varietas-varietas terbaik, selera petani terhadap varietas unggul dapat berbeda dan sangat beragam antar daerah. Program seleksi varietas partisipatif (participatory varietal selection $=P V S$ ) dikembangkan untuk meningkatkan efisiensi seleksi yang dilakukan pemulia dengan melibatkan petani sebagai pengguna akhir produk pemuliaan dalam proses seleksi. Dua kegiatan seleksi varietas partisipatif dilakukan pada musim hujan 2012-2013 di dua sentra padi gogo yakni Cianjur (Jawa Barat) dan Kebumen (Jawa Tengah). Sepuluh galur harapan padi gogo dan empat varietas unggul pembanding digunakan dalam kegiatan PVS. Masing-masing galur atau varietas ditanam oleh seorang petani kooperator dengan luas tanam $2000 \mathrm{~m}^{2}$ sampai $2500 \mathrm{~m}^{2}$. Budidaya padi dilakukan oleh petani berdasarkan paket rekomendasi dari peneliti. Seleksi dilakukan pada saat menjelang panen dengan melibatkan sebanyak 20 sampai 22 orang petani di masing-masing lokasi. Hasil PVS menunjukkan keragaman preferensi petani di dalam dan antar daerah. Hasil penelitian ini mengindikasikan adanya kesesuaian antar nilai preferensi varietas hasil seleksi petani dengan nilai penerimaan fenotipe oleh pemulia. Namun demikian tidak semua genotipe dengan nilai preferensi yang tinggi menghasilkan gabah yang tinggi, mengindikasikan bahwa komponen hasil bukan satu-satunya penentu preferensi petani dalam mengadopsi varietas unggul. Dampak dari pelaksanaan PVS terhadap adopsi varietas unggul, peningkatan keragaman genetik di lapang dan sarana penyebaran benih informal didiskusikan dalam tulisan ini.

Kata kunci: Seleksi Galur, Partisipatif, Padi Gogo 


\section{PENDAHULUAN}

Varietas unggul padi yang adaptif terhadap kondisi lahan kering merupakan komponen teknologi utama dalam usaha peningkatan produksi padi di lahan kering. Sifat-sifat penting yang menjadi sasaran perbaikan varietas padi untuk lahan kering antara lain hasil tinggi, toleran terhadap cekaman kekeringan, keracunan aluminum, tahan terhadap penyakit blas dan memiliki mutu beras yang baik (Lubis et al., 2008; Cruz et al., 2009; Suwarno et al., 2009). Dalam program pemuliaan yang formal, seleksi untuk mendapatkan sifat-sifat tersebut biasanya dilakukan oleh pemulia di kebun-kebun percobaan (Witcombe et al., 1996; Atlin et al., 2001).

Salah satu permasalahan yang sering muncul dalam program pemuliaan formal adalah rendahnya tingkat adopsi petani terhadap varietasvarietas unggul hasil pemuliaan (Witcombe et al., 1996; Atlin et al., 2001). Masalah tersebut diduga salah satunya disebabkan oleh sangat beragamnya preferensi petani terhadap suatu varietas baik itu dari morfologi tanaman maupun mutu beras yang dihasilkan (Almekinders dan Elings, 2001; Singh et al., 2013). Preferensi yang sangat beragam antar daerah atau bahkan antar petani membutuhkan ketersediaan pilihan varietas yang lebih beragam dari pemulia. Program seleksi varietas secara partisipatif (participatory varietal selection $=$ PVS) dikembangkan untuk meningkatkan keterlibatan petani dalam pemilihan suatu varietas yang akan dilepas untuk mempercepat proses adopsi varietas oleh petani (Witcombe et al. 1996; Almekinders dan Elings, 2001). Melalui PVS petani dilibatkan untuk memberikan masukan kepada pemulia tipe tanaman padi yang dikehendaki. Dalam PVS galur-galur harapan hasil pemuliaan ditanam di lahan petani dan petani diberi kesempatan untuk mengevaluasi galur-galur tersebut (Witcombe $e t$ al., 1996; Atlin et al., 2001). Melalui pendekatan ini diharapkan varietas yang dilepas benar-benar sesuai dengan preferensi petani sehingga lebih cepat diadopsi.

Di lahan kering masalah lain yang diduga menyebabkan rendahnya adopsi varietas unggul padi gogo adalah mudah patahnya ketahanan varietas-varietas unggul yang dilepas terhadap penyakit blas, menyebabkan petani enggan untuk menanam kembali varietas yang peka (Suwarno et al., 2009). Seleksi varietas partisipatif dapat menjadi salah satu strategi untuk menyebarkan varietas-varietas unggul dengan beragam ketahanan terhadap penyakit blas (Hairmansis et al., 2008). Difusi galur-galur harapan dengan spektrum ketahanan terhadap blas yang beragam melalui PVS diharapkan mampu meningkatkan keragaman genetik di lapang yang merupakan strategi utama pengendalian penyakit blas (Hairmansis et al., 2008; Cruz et al., 2009; Suwarno et al., 2009; Gallet et al., 2014). Preferensi yang berbeda antar petani menjadi instrumen penting untuk tetap menjaga keragaman genetik di lapang (Witcombe et al., 2001)

Hal lain yang sering menjadi penghambat dalam pengembangan varietas unggul padi gogo adalah rendahnya dukungan sistem perbenihan formal dalam penyediaan benih varietas unggul padi gogo (Wahyuni et al., 2006; Wahyuni, 2008). Pendekatan PVS dapat membantu menjembatani penyebaran benih varietas unggul yang sulit dilaksanakan melalui sistem perbenihan formal (Lacoste et al., 2012). Melalui PVS transfer benih varietas unggul dapat berlangsung karena petani saling berbagi varietas unggul atau galur harapan yang disukai dengan petani-petani yang lain.

Seleksi varietas partisipatif yang dilaksanakan dalam penelitian ini bertujuan untuk menyeleksi galur-galur harapan padi gogo yang sesuai dengan preferensi petani, khususnya di daerah Cianjur dan Kebumen yang merupakan sentra pertanaman padi gogo di Jawa Barat dan Jawa Tengah dan untuk menyebarkan varietas unggul dan galur harapan di lahan kering sebagai sarana difusi informal untuk meningkatkan keragaman genetik dan ketersediaan benih padi gogo.

\section{BAHAN DAN METODE}

Sepuluh galur harapan padi gogo hasil pemuliaan Balai Besar Penelitian Tanaman Padi (BB Padi) dan empat varietas unggul baru padi gogo digunakan dalam seleksi partisipatif (Tabel 1). Percobaan dilakukan di dua lokasi yaitu Desa Muara Kadu, Kecamatan Sindangbarang, Kabupaten Cianjur, Jawa Barat dan Desa Wiromartan, Kecamatan Mirit, Kabupaten Kebumen, Jawa Tengah pada musim hujan (MH) 2012-2013. Benih galur dan varietas yang dievaluasi dikemas dalam kantong $5 \mathrm{~kg}$ dan dibagikan secara acak kepada 14 petani di masing-masing lokasi. Luas tanam di setiap petani disesuaikan dengan luasan tanah garapannya yang berkisar antara $2000-2500 \mathrm{~m}^{2}$ per petani. Budidaya padi gogo dilaksanakan sesuai rekomendasi dari peneliti dengan menggunakan jarak tanam $30 \mathrm{~cm}$ (antar barisan) $\times 15 \mathrm{~cm}$ (dalam 
barisan). Pemupukan terdiri atas $100 \mathrm{~kg}$ urea per ha dan $300 \mathrm{~kg}$ NPK (Ponska) per ha dengan rincian: $200 \mathrm{~kg}$ NPK diberikan saat 10 hari setelah tanam (hst), $100 \mathrm{~kg}$ urea saat $35 \mathrm{hst}$ dan $100 \mathrm{~kg}$ NPK saat primordia bunga. Penyiangan dilakukan saat umur 3 minggu setelah tanam dan pada umur 7 minggu setelah tanam. Pengamatan terhadap karakter-karakter agronomi dan respon genotipe terhadap serangan penyakit blas tanaman padi mengacu pada sistem evaluasi padi yang telah baku (IRRI, 1996).

Data preferensi petani terhadap galur dan varietas yang ditanam dikumpulkan dengan melakukan evaluasi secara partisipatif yang melibatkan 20 sampai dengan 22 orang petani melalui sebuah temu lapang. Setiap petani diberi dua tipe kartu yaitu kartu berwarna kuning yang mengindikasikan pilihan "suka" dan kartu berwarna biru yang menunjukkan pilihan "tidak suka". Setiap petani memberikan tanggapan terhadap masing-masing galur atau varietas dengan cara memasukkan salah satu kartu sesuai pilihannya ke dalam kotak yang telah disediakan pada setiap plot galur dan varietas yang diuji. Nilai preferensi varietas (Paris et al., 2011) masing-masing galur dan varietas yang diuji diperoleh dengan menghitung jumlah kartu yang berada dalam kotak dan dengan menggunakan persamaan:

$$
\text { Nilai preferensi varietas }=\frac{\text { Jumlah suara suka- jumlah suara tidak suka }}{\text { Jumlah total suara }}
$$

Tabel 1. Galur dan varietas padi gogo yang digunakan dalam seleksi varietas partisipatif di Cianjur dan Kebumen.

\begin{tabular}{cll}
\hline No & Galur & Persilangan \\
\hline 1 & B11593F-MR-48 & Dupa/Cabacu \\
2 & TB490-TB-1-2-1-MR-29 & Batutegi/Cigeulis//Ciherang \\
3 & B12497E-MR-45 & IR68886/BP68*10//Selegreng//Guarani/Asahan \\
4 & B12790E-TB-2-1 & IUF5-22/IUF5-52//IR69502-SKN-UBN-1-B-1-3 \\
5 & B11576F-MR-18-2 & G.Mungkur/Cabacu//Bulan Sabit/Memberamo \\
6 & TB401B-TB-21-2 & Cirata/Widas \\
7 & B11592F-MR-16-1-5-4 & IR60080-23/BP303 \\
8 & B12158E-TB-1 & Limboto/Cimelati \\
9 & TB368B-MR-25-1-1 & Limboto/Way Apuburu \\
10 & B11597C-TB-2-24-1 & IR60080-23//IRBL 8/IRBL 10. \\
11 & Inpago 8 & Varietas unggul \\
12 & Batutugi & Varietas unggul \\
13 & Limboto & Varietas unggul \\
14 & Situpatenggang & Varietas unggul \\
\hline
\end{tabular}

\section{HASIL DAN PEMBAHASAN}

\section{Pembentukan galur harapan padi gogo bahan seleksi varietas partisipatif}

Sepuluh galur harapan padi gogo digunakan sebagai materi seleksi varietas partisipatif di Cianjur dan Kebumen. Galur-galur tersebut merupakan galur generasi lanjut yang telah diseleksi oleh pemulia di kebun percobaan Tamanbogo (Lampung) yang mewakili lahan gogo dengan tipe lahan podsolik merak kuning. Selain itu galur-galur tersebut juga telah melalui sejumlah skrining untuk ketahanan terhadap penyakit blas dan toleransi terhadap cekaman abiotik seperti keracunan aluminum dan kekeringan. Kesepuluh galur tersebut merupakan kandidat galur yang akan diujikan dalam uji multilokasi sebagai syarat pelepasan varietas unggul. 
Program seleksi varietas partisipatif (PVS) dilakukan dengan menanam sejumlah galur elit di lahan petani untuk memberi kesempatan kepada petani untuk memilih galur yang disukai (Atlin $e t$ al., 2001; Witcombe et al., 1996). Metode tersebut berbeda dengan pemuliaan partisipatif (participatory plant breeding $=\mathrm{PBB})$. Dalam PBB petani dilibatkan dalam seleksi sejak generasi awal (generasi bersegregasi) (Atlin et al., 2001). Penggunaan galur harapan dalam jumlah yang sedikit dalam PVS bertujuan untuk memudahkan petani dalam memilih galur yang disukai. Selain itu penggunaan galur generasi lanjut juga bertujuan agar galur yang dipilih oleh petani merupakan galur-galur yang telah homogen dan siap untuk diusulkan sebagai varietas unggul baru.

\section{Penampilan agronomi dan preferensi petani terhadap galur dan varietas padi gogo di Cianjur \\ Sepuluh galur harapan dan empat varietas} unggul baru padi gogo ditanam di lahan 14 petani kooperator di Cianjur (Tabel 2). Masing-masing petani mendapat kesempatan untuk menanam 1 genotipe dengan teknik budidaya sesuai anjuran peneliti. Sifat-sifat agronomi galur dan varietas padi gogo diamati sebelum panen (Tabel 2). Umur panen galur-galur padi gogo lebih genjah dibandingkan dengan varietas Batutegi dan setara dengan varietas Limboto, Situpatenggang dan Inpago 8 (Tabel 2). Semua galur dan varietas yang dievaluasi menunjukkan ketahanan yang baik terhadap serangan penyakit blas di lapang. Tiga galur menunjukkan respon agak tahan terhadap blas leher yaitu B12790E-TB-2-1, B11576F-MR18-2 dan B11592F-MR-16-1-5-4 (Tabel 2).

Nilai penerimaan fenotipe masing-masing genotipe (phenotypic acceptability score) dinilai oleh pemulia menjelang panen (IRRI, 1996). Berdasarkan fenotipenya, varietas Limboto dan Situpatenggang menunjukkan penampilan yang lebih baik dibandingkan galur-galur harapan, sementara diantara 10 galur yang diuji, B12790E-TB-2-1 dan TB368B-MR-25-1-1 menunjukkan performa yang terbaik (Tabel 2).

Tabel 2. Penampilan agronomi dan ketahanan terhadap penyakit blas genotipe padi gogo di 14 petani koperator di Cianjur Jawa Barat pada MH 2012-2013

\begin{tabular}{|c|c|c|c|c|c|c|c|c|}
\hline \multirow{2}{*}{$\begin{array}{c}\text { Petani } \\
\text { Koperator }\end{array}$} & \multirow[b]{2}{*}{ Genotipe } & \multirow{2}{*}{$\begin{array}{l}\text { Luas } \\
\text { plot } \\
\left(\mathrm{m}^{2}\right)\end{array}$} & \multirow{2}{*}{$\begin{array}{c}\text { Tinggi } \\
\text { tanaman } \\
(\mathrm{cm})\end{array}$} & \multirow{2}{*}{$\begin{array}{l}\text { Jumlah } \\
\text { anakan }\end{array}$} & \multirow{2}{*}{$\begin{array}{l}\text { Umur } \\
\text { panen } \\
\text { (hari) }\end{array}$} & \multicolumn{2}{|c|}{$\begin{array}{l}\text { Skor ketahanan } \\
\text { terhadap blas }{ }^{1)}\end{array}$} & \multirow{2}{*}{$\begin{array}{c}\text { Peneri- } \\
\text { maan } \\
\text { fenotipe }^{2)}\end{array}$} \\
\hline & & & & & & $\begin{array}{l}\text { Blas } \\
\text { leher }\end{array}$ & $\begin{array}{l}\text { Blas } \\
\text { daun }\end{array}$ & \\
\hline 1 & B11593F-MR-48 & 2500 & 143,00 & 15,33 & 116 & 1 & 1 & 5 \\
\hline 2 & TB490-TB-1-2-1-MR-29 & 2500 & 140,00 & 7,33 & 115 & 0 & 0 & 5 \\
\hline 3 & B12497E-MR-45 & 2500 & 115,00 & 13,00 & 100 & 0 & 0 & 5 \\
\hline 4 & B12790E-TB-2-1 & 2500 & 100,67 & 11,33 & 100 & 3 & 1 & 3 \\
\hline 5 & B11576F-MR-18-2 & 2500 & 136,00 & 11,67 & 115 & 3 & 1 & 5 \\
\hline 6 & TB401B-TB-21-2 & 2500 & 140,33 & 11,00 & 115 & 0 & 3 & 5 \\
\hline 7 & B11592F-MR-16-1-5-4 & 2500 & 135,00 & 9,67 & 100 & 3 & 0 & 5 \\
\hline 8 & B12158E-TB-1 & 2500 & 140,33 & 12,00 & 112 & 0 & 3 & 5 \\
\hline 9 & TB368B-MR-25-1-1 & 2500 & 120,33 & 18,33 & 115 & 0 & 0 & 3 \\
\hline 10 & B11597C-TB-2-24-1 & 2500 & 140,33 & 11,00 & 115 & 0 & 0 & 5 \\
\hline 11 & Inpago 8 & 2500 & 133,00 & 13,00 & 115 & 0 & 0 & 5 \\
\hline 12 & Batutegi & 2500 & 139,33 & 9,67 & 130 & 0 & 3 & 5 \\
\hline 13 & Limboto & 2500 & 107,33 & 9,00 & 110 & 0 & 0 & 1 \\
\hline 14 & Situpatenggang & 2500 & 107,00 & 9,67 & 110 & 0 & 0 & 1 \\
\hline
\end{tabular}

1) Skor ketahanan terhadap penyakit blas: $0=$ sangat tahan, $1=$ tahan, $3=$ agak tahan, $5=$ agak peka, $7=$ peka, $9=$ sangat peka

2) Penerimaan fenotipe: $1=$ sangat baik, $3=$ baik, $5=$ moderat, $7=$ jelek, $9=$ sangat jelek 
Seleksi varietas partisipatif dilaksanakan melalui temu lapang saat menjelang panen dengan mengundang 22 orang petani sebagai panelis. Para petani diajak berkeliling ke demplot-demplot galur di 14 petani kooperator dan diminta untuk mengamati pertanaman secara detail. Data preferensi petani terhadap galur-galur yang ditanam dikumpulkan dengan menggunakan kartu suara (Paris et al., 2011). Masing-masing petani diberikan 2 pilihan suara antara suka dan tidak suka terhadap masing-masing galur (Tabel 3). Hasil penghitungan suara menunjukkan galur B12790E-TB-2-1 memiliki skor preferensi tertinggi $(0,82)$ dibandingkan galur-galur yang lain. Nilai preferensi galur tersebut sama dengan varietas Limboto dan Situpatenggang (Tabel 3). Nilai preferensi terendah ditunjukkan oleh galur B11597C-TB-2-24-1 (-0.91).

Hasil diskusi dengan petani saat temu lapang menunjukkan sejumlah sifat yang menjadi pertimbangan utama petani pada saat memilih tanaman yang disukai antara lain kekuatan batang (kerebahan) dan umur tanaman. Sebagian besar genotipe yang mendapat nilai pereferensi negatif mengalami kerebahan saat dilakukan temu lapang seperti galur B11597C-TB-2-24-1, B11576F-MR18-2, dan B11592F-MR-16-1-5-4. Varietas Batutegi memiliki skor preferensi terendah di antara empat varietas unggul pembanding disebabkan umurnya yang lambat (130 hari) (Tabel 2 dan Tabel 3).

Hasil seleksi partisipatif yang dilakukan di Cianjur menunjukkan adanya keragaman pilihan antar petani. Yang menarik adalah semua galur dan varietas mendapatkan kartu suara positif dengan jumlah yang berbeda, mengindikasikan adanya kelebihan spesifik yang diminati oleh petani di masing-masing galur atau varietas. Selain itu terdapat kesesuaian antara skor phenotypic acceptability yang dilakukan pemulia dengan nilai preferensi genotipe hasil PVS.

Tabel 3. Nilai preferensi (preference score) dan hasil gabah genotipe padi gogo di lahan petani Cianjur, Jawa Barat pada MH 2012-2013

\begin{tabular}{clccccc}
\hline $\begin{array}{c}\text { Petani } \\
\text { Koperator }\end{array}$ & \multicolumn{1}{c}{ Genotipe } & $\begin{array}{c}\text { Jumlah } \\
\text { Responden }\end{array}$ & $\begin{array}{c}\text { Jumlah } \\
\text { Suara } \\
\text { Suka }\end{array}$ & $\begin{array}{c}\text { Jumlah } \\
\text { Suara } \\
\text { Tidak Suka }\end{array}$ & $\begin{array}{c}\text { Nilai } \\
\text { Preferensi }\end{array}$ & $\begin{array}{c}\text { Hasil } \\
\text { t/ha) }\end{array}$ \\
\hline 1 & B11593F-MR-48 & 22 & 12 & 10 & 0,09 & 6,49 \\
2 & TB490-TB-1-2-1-MR-29 & 22 & 10 & 12 & $-0,09$ & 6,59 \\
3 & B12497E-MR-45 & 22 & 6 & 16 & $-0,45$ & 4,81 \\
4 & B12790E-TB-2-1 & 22 & 20 & 2 & 0,82 & 6,8 \\
5 & B11576F-MR-18-2 & 22 & 3 & 19 & $-0,73$ & 6,49 \\
6 & TB401B-TB-21-2 & 22 & 5 & 17 & $-0,55$ & 6,49 \\
7 & B11592F-MR-16-1-5-4 & 22 & 3 & 19 & $-0,73$ & 4,81 \\
8 & B12158E-TB-1 & 22 & 4 & 18 & $-0,64$ & 6,17 \\
9 & TB368B-MR-25-1-1 & 22 & 19 & 3 & 0,73 & 5,13 \\
10 & B11597C-TB-2-24-1 & 22 & 1 & 21 & $-0,91$ & 6,28 \\
11 & Inpago 8 & 22 & 16 & 6 & 0,45 & 6,28 \\
12 & Batutegi & 22 & 9 & 13 & $-0,18$ & 4,71 \\
13 & Limboto & 22 & 20 & 2 & 0,82 & 5,34 \\
14 & Situpatenggang & 22 & 20 & 2 & 0,82 & 6,07 \\
\hline
\end{tabular}

Panen dilakukan setelah pelaksanaan seleksi partisipatif. Hasil pengambilan sampel gabah kering giling menunjukkan galur B12790E-TB-21 memiliki hasil gabah tertinggi (6.8 t/ha), lebih tinggi dibandingkan semua varietas pembanding. Galur TB490-TB-1-2-1-MR-29 memberikan hasil tertinggi kedua yakni 6.59 t/ha. Hal yang menarik adalah tidak semua galur dengan nilai preferensi yang tinggi menghasilkan gabah yang tinggi, demikian juga sebaliknya tidak semua galur dengan hasil gabah yang tinggi (lebih tinggi dari pembanding) mempunyai nilai preferensi yang tinggi atau disukai oleh petani, seperti galur B11576F-MR-18-2 (6.49 t/ha), TB401B-TB-21-2 (6.49 t/ha), dan B11597C-TB-2-24-1 (6.28 t/ha). Nilai preferensi dari galur tersebut berturut-turut 
adalah $-0,73,-0,55$ dan $-0,91$ (Tabel 3). Hal tersebut mengindikasikan komponen hasil bukan merupakan satu-satunya penentu preferensi petani.

\section{Preferensi petani dan penampilan agronomi galur dan varietas padi gogo di Kebumen}

Sebanyak 14 petani kooperator di Kebumen, Jawa Tengah dilibatkan untuk menanam salah satu dari 10 galur dan 4 varietas unggul baru padi gogo (Tabel 4). Sifat-sifat agronomi dari galurgalur dan varietas padi gogo diamati sebelum panen (Tabel 4). Beberapa galur seperti B12497EMR-45, B12790E-TB-2-1, dan B11592F-MR-161-5-4 memiliki umur panen yang lebih genjah dibandingkan semua varietas pembanding (Tabel 4).

Respon semua genotipe yang dievaluasi terhadap penyakit blas daun dan blas leher di lapang menunjukkan nilai yang sama yakni skor 1 (Tabel 4). Hal tersebut dapat disebabkan oleh dua kemungkinan yakni pertama karena genotipe yang dievaluasi tahan terhadap ras blas yang ada di lapang atau kedua akibat rendahnya virulensi ras blas di lapang saat percobaan dilaksanakan tergolong rendah.

Berdasarkan skor penerimaan fenotipe (phenotypic acceptability) oleh pemulia, genotipe yang memiliki penampilan terbaik adalah Inpago 8 dan Situpatenggang (Tabel4).

Tabel 4. Penampilan agronomi dan ketahanan terhadap penyakit blas genotipe padi gogo di 14 petani koperator di Kebumen, Jawa Tengah pada MH 2012-2013

\begin{tabular}{|c|c|c|c|c|c|c|c|c|}
\hline \multirow{2}{*}{$\begin{array}{c}\text { Petani } \\
\text { Koperator }\end{array}$} & \multirow{2}{*}{ Genotipe } & \multirow{2}{*}{$\begin{array}{l}\text { Luas } \\
\text { plot } \\
\left(\mathrm{m}^{2}\right)\end{array}$} & \multirow{2}{*}{$\begin{array}{l}\text { Tinggi } \\
\text { tanaman } \\
(\mathrm{cm})\end{array}$} & \multirow{2}{*}{$\begin{array}{l}\text { Jumlah } \\
\text { anakan }\end{array}$} & \multirow{2}{*}{$\begin{array}{l}\text { Umur } \\
\text { panen } \\
\text { (hari) }\end{array}$} & \multicolumn{2}{|c|}{$\begin{array}{c}\text { Skor } \\
\text { ketahanan } \\
\text { terhadap blas }{ }^{1)}\end{array}$} & \multirow{2}{*}{$\begin{array}{l}\text { Penerimaan } \\
\text { fenotipe }^{2)}\end{array}$} \\
\hline & & & & & & $\begin{array}{l}\text { Blas } \\
\text { leher }\end{array}$ & $\begin{array}{l}\text { Blas } \\
\text { daun }\end{array}$ & \\
\hline 1 & B11593F-MR-48 & 2000 & 140,67 & 8,67 & 112 & 1 & 1 & 3 \\
\hline 2 & TB490-TB-1-2-1-MR-29 & 2000 & 131,67 & 8,00 & 110 & 1 & 1 & 3 \\
\hline 3 & B12497E-MR-45 & 2000 & 78,67 & 5,67 & 99 & 1 & 1 & 7 \\
\hline 4 & B12790E-TB-2-1 & 2000 & 119,33 & 16,00 & 99 & 1 & 1 & 3 \\
\hline 5 & B11576F-MR-18-2 & 2000 & 133,33 & 15,67 & 110 & 1 & 1 & 3 \\
\hline 6 & TB401B-TB-21-2 & 2000 & 93,33 & 9,00 & 111 & 1 & 1 & 5 \\
\hline 7 & B11592F-MR-16-1-5-4 & 2000 & 125,33 & 9,00 & 99 & 1 & 1 & 5 \\
\hline 8 & B12158E-TB-1 & 2000 & 123,67 & 13,67 & 109 & 1 & 1 & 5 \\
\hline 9 & TB368B-MR-25-1-1 & 2000 & 118,00 & 12,33 & 112 & 1 & 1 & 5 \\
\hline 10 & B11597C-TB-2-24-1 & 2000 & 134,67 & 8,33 & 113 & 1 & 1 & 5 \\
\hline 11 & Inpago 8 & 2000 & 133,33 & 11,00 & 113 & 1 & 1 & 1 \\
\hline 12 & Batutegi & 2000 & 125,33 & 12,00 & 123 & 1 & 1 & 3 \\
\hline 13 & Limboto & 2000 & 108,67 & 10,00 & 108 & 1 & 1 & 3 \\
\hline 14 & Situpatenggang & 2000 & 116,00 & 11,00 & 107 & 1 & 1 & 1 \\
\hline
\end{tabular}

1) Skor ketahanan terhadap penyakit blas: $0=$ sangat tahan, $1=$ tahan, $3=$ agak tahan, $5=$ agak peka, $7=$ peka, $9=$ sangat peka

2) Penerimaan fenotipe: $1=$ sangat baik, $3=$ baik, $5=$ moderat, $7=$ jelek, $9=$ sangat jelek

Seleksi partisipatif di Kebumen melibatkan 20 orang petani. Hasil seleksi menunjukkan dua varietas unggul baru yang telah dilepas Inpago 8 dan Situpatenggang memiliki nilai preferensi tertinggi yakni 1 . Hal tersebut mengindikasikan semua petani menyukai kedua varietas tersebut. Diantara galur yang diuji, galur B11576F-MR-182 dan B12790E-TB-2-1 memiliki skor preferensi tertinggi, masing - masing 0.8 dan 0.7 (Tabel 5). Penilaian oleh petani di Kebumen pada saat PVS dilakukan sangat dipengaruhi oleh serangan hama uret terhadap pertanaman di lapang. Beberapa galur mengalami kerusakan serius akibat serangan hama uret seperti B12497E-MR-45, B11597CTB-2-24-1, TB368B-MR-25-1-1, dan TB401BTB-21-2, menyebabkan nilai preferensi galurgalur tersebut rendah. Selain itu umur panen juga menjadi pertimbangan penting yang diindikasikan dengan sangat rendahnya nilai preferensi varietas 
Batutegi (-1) yang memiliki umur paling dalam (Tabel 4 dan 5).

\section{Peranan PVS dalam pemuliaan dan peningkatan produksi padi gogo}

Hasil pelaksanaan PVS di dua lokasi sentra padi gogo Cianjur dan Kebumen menunjukkan adanya keragaman preferensi antar petani. Melalui pelaksanaan PVS ini teridentifikasi galurgalur yang potensial untuk dilepas dan memenuhi preferensi petani. Hasil PVS menunjukkan 6 genotipe di Cianjur (Tabel 3) dan 7 genotipe di Kebumen (Tabel 5) mendapatkan nilai preferensi positif mengindikasikan galur-galur tersebut diterima oleh sebagian besar petani. Informasi yang diperoleh dalam program ini sangat bermanfaat untuk menunjang usaha pelepasan galur-galur harapan yang diuji menjadi varietas unggul. Selain itu varietas unggul yang nantinya dilepas juga diharapkan lebih mudah diterima dan diadopsi oleh petani karena sifat - sifat yang dibawa sesuai dengan preferensi petani. Namun demikian seleksi partisipatif perlu juga dilaksanakan di sejumlah lokasi lain khususnya sentra-sentra produksi padi gogo agar informasi preferensi menjadi lebih lengkap.

Tabel 5. Nilai preferensi (preference score) dan hasil gabah genotipe padi gogo di lahan petani Kebumen, Jawa Tengah pada MH 2012-2013

\begin{tabular}{clccccc}
\hline $\begin{array}{c}\text { Petani } \\
\text { Koperator }\end{array}$ & \multicolumn{1}{c}{ Genotipe } & $\begin{array}{c}\text { Jumlah } \\
\text { Responden }\end{array}$ & $\begin{array}{c}\text { Jumlah } \\
\text { Suara } \\
\text { Suka }\end{array}$ & $\begin{array}{c}\text { Jumlah } \\
\text { Suara Tidak } \\
\text { Suka }\end{array}$ & $\begin{array}{c}\text { Nilai } \\
\text { preferensi }\end{array}$ & $\begin{array}{c}\text { Hasil } \\
(\mathrm{t} / \mathrm{ha})\end{array}$ \\
\hline 1 & B11593F-MR-48 & 20 & 16 & 4 & 0,6 & 6,36 \\
2 & TB490-TB-1-2-1-MR-29 & 20 & 10 & 10 & 0 & 5,88 \\
3 & B12497E-MR-45 & 20 & 8 & 12 & $-0,2$ & 0,60 \\
4 & B12790E-TB-2-1 & 20 & 17 & 3 & 0,7 & 7,20 \\
5 & B11576F-MR-18-2 & 20 & 18 & 2 & 0,8 & 8,04 \\
6 & TB401B-TB-21-2 & 20 & 7 & 13 & $-0,3$ & 4,20 \\
7 & B11592F-MR-16-1-5-4 & 20 & 9 & 11 & $-0,1$ & 5,16 \\
8 & B12158E-TB-1 & 20 & 14 & 6 & 0,4 & 6,72 \\
9 & TB368B-MR-25-1-1 & 20 & 6 & 14 & $-0,4$ & 4,80 \\
10 & B11597C-TB-2-24-1 & 20 & 5 & 15 & $-0,5$ & 5,04 \\
11 & Inpago 8 & 20 & 20 & 0 & 1 & 5,76 \\
12 & Batutegi & 20 & 0 & 20 & -1 & 6,00 \\
13 & Limboto & 20 & 19 & 1 & 0,9 & 6,00 \\
14 & Situpatenggang & 20 & 20 & 0 & 1 & 4,08 \\
\hline
\end{tabular}

Pelaksanaan PVS ini juga memiliki peran penting dalam peningkatan keragaman genetik padi di lapang dan sebagai jalur informasil difusi benih varietas unggul padi gogo di lahan petani (Witcombe et al., 2001; Hairmansis et al., 2008; Suwarno et al., 2009; Lacoste et al., 2012). Keragaman preferensi yang tercermin dalam pelaksanaan PVS di Cianjur dan Kebumen merupakan modal penting dalam usaha meningkatkan keragaman genetik di lapang. Diharapkan para petani dapat terus melanjutkan menanam galur atau varietas yang disukai sesuai selera masing-masing dan berbagi benihnya dengan petani non-kooperator yang lain. Melalui jalan tersebut akan terbentuk keragaman genetik yang luas di lapang yang merupakan strategi penting dalam pengendalian penyakit blas (Suwarno et al., 2009; Gallet et al., 2014). Hal penting lain yang perlu dilakukan adalah monitoring terhadap keberlanjutan program tersebut. Hasil penelitian Witcombe et al. (2001) menunjukkan biodiversitas tanaman padi dapat meningkat secara nyata tiga musim setelah dilakukan PVS. Penelitian Lacoste et al. (2012) juga menunjukkan strategi difusi benih varietas unggul melalui pendekatan partisipatif mampu secara signifikan meningkatkan jumlah petani yang mengadopsi varietas unggul setelah tiga tahun program tersebut berjalan. Oleh karenanya penelitian lebih lanjut untuk mengevaluasi dampak PVS yang telah dilakukan di Cianjur dan Kebumen akan sangat bermanfaat. 


\section{KESIMPULAN}

Seleksi varietas secara partisipatif terhadap galur-galur harapan padi gogo berhasil mengidentifikasi galur-galur padi gogo yang sesuai dengan preferensi petani di Cianjur dan Kebumen. Keragaman dalam preferensi petani di dalam dan antar daerah memberikan peluang peningkatan keragaman genetik padi di lahan kering sebagai strategi utama dalam pengendalian penyakit blas. Pengujian beragam galur dan varietas di lahan petani juga dapat menjadi strategi penting untuk penyebaran benih varietas unggul di lahan kering.

\section{UCAPAN TERIMA KASIH}

Penelitian ini dilaksanakan melalui anggaran DIPA Balai Besar Penelitian Tanaman Padi. Terimakasih penulis sampaikan kepada seluruh petani kooperator dalam program PVS, Dinas Pertanian Kabupaten Cianjur dan Dinas Pertanian Kabupaten Kebumen atas kerjasama yang diberikan selama pelaksanaan penelitian

\section{DAFTAR PUSTAKA}

Almekinders, C.J.M., Elings, A. 2001. Collaboration of farmers and breeders: Participatory crop improvement in perspective. Euphytica 122 (3): 425-438.

Atlin, G.N., Cooper, M., Bjørnstad, A. 2001. A comparison of formal and participatory breeding approaches using selection theory. Euphytica 122 (3): 463-475.

Cruz, C.V., Castilla, N., Suwarno, S., Hondrade, E., Hondrade, R., Paris, T., Elazegui, F. 2009. Rice disease management in the uplands of Indonesia and the Philippines. In. S.M. Haefele and A.M. Ismail (Eds). Natural resource management for proverty reduction and environmental sustainability in fragile rice-based systems. Limited Proceedings No 15. IRRI. Manila. Philippines. pp 10-18.

Gallet, R., Bonnot, F., Milazzo, J., Tertois, C., Adreit, H., Ravigné, V., Tharreau, D., Fournier, E. 2014. The variety mixture strategy assessed in a GXG experiment with rice and the blast fungus Magnaporthe oryzae. Frontiers in Genetics 4: 1-11.

Hairmansis, A., Kustianto, B., Lubis, E., Suwarno. 2008. Increasing genetic diversity through participatory varietal selection of upland rice in Lampung. Penelitian Pertanian Tanaman Pangan 27(1): 9-12.

IRRI. 1996. Standard evaluation system for rice. IRRI. Manila. Philippines. 52p.

Lacoste, M., Williams, R., Erskine, W., Nesbitt, H., Pereira, L., Marçal, A. 2012. Varietal diffusion in marginal seed systems: Participatory trials initiate change in East Timor. Journal of Crop Improvement 26 (4): 468-488.

Lubis, E., Hermanasari, R., Sunaryo, A.S., Suparman, E. 2008. Toleransi galur padi gogo terhadap cekaman abiotik. Prosiding Seminar Apresiasi Hasil Penelitian Padi Menunjang P2BN. Buku 2. Balai Besar Penelitian Tanaman Padi. Sukamandi. pp. 725-739.

Paris, T., Manzanilla, D., Tatlonghari, G., Labios, R., Cueno, A., Villanueva, D. 2011. Guide to participatory varietal selection for submergence-tolerant rice. IRRI. Manila. Philippines. 111p.

Singh, Y.P., Nayak, A.K., Sharma, D.K., Gautam, R.K., Singh, R.K., Singh, R., Mishra, V.K., Paris, T., Ismail, A.M. 2013. Farmers' participatory varietal selection: A sustainable crop improvement approach for the 21st century. Agroecology and Sustainable Food Systems 38 (4): 427-444.

Suwarno, Lubis, E., Hairmansis, A., Santoso. 2009. Development of a package of 20 varieties for blast management on upland rice. In. G.L. Wang and B. Valent (eds). Advances in Genetics, Genomics and Control of Rice Blast Disease. Springer Netherlands. pp. 347357.

Wahyuni, S. 2008. Hasil padi gogo dari dua sumber benih yang berbeda. Jurnal Penelitian Tanaman Pangan 27 (3): 135-140.

Wahyuni, S., Kadir, T.S., Nugraha, U.S. 2006. Hasil dan mutu benih padi gogo pada lingkungan tumbuh berbeda. Penelitian Pertanian Tanaman Pangan 25 (1): 30-37.

Witcombe, J., Joshi, A., Joshi, K., Sthapit, B. 1996. Farmer participatory crop improvement. I. Varietal selection and breeding methods and their impact on biodiversity. Experimental Agriculture 32 (4): 445-460.

Witcombe, J., Joshi, K., Rana, R., Virk, D. 2001. Increasing genetic diversity by participatory varietal selection in high potential production systems in Nepal and India. Euphytica 122 (3): $575-588$. 